\title{
On Measurement of Efficiency of Cobb-Douglas Production Function with Additive and Multiplicative Errors
}

\author{
Md. Moyazzem Hossain ${ }^{1, *}$ and Ajit Kumar Majumder ${ }^{1}$ \\ ${ }^{1}$ Department of Statistics, Jahangirnagar University, Savar, Dhaka, Bangladesh
}

Received: 6 December 2014; Accepted: 7 February 2015

Editor: Paulo Rodrigues

\begin{abstract}
In developing counties, efficiency of economic development has determined by the analysis of industrial production. An examination of the characteristic of industrial sector is an essential aspect of growth studies. The most of the developed countries are highly industrialized as they brief "The more industrialization, the more development". For proper industrialization and industrial development we have to study industrial input-output relationship that leads to production analysis. For a number of reasons econometrician's belief that industrial production is the most important component of economic development because, if domestic industrial production increases, GDP will increase, if elasticity of labor is higher, implement rates will increase and investment will increase if elasticity of capital is higher. In this regard, this paper choose and estimate the parameters of Cobb-Douglas function with additive errors and multiplicative errors for some selected manufacturing industries of Bangladesh over the period 1978-79 to 2011-2012, which should be helpful in suggesting the most suitable Cobb-Douglas production function to forecast the production process for some selected manufacturing industries of developing countries like Bangladesh. This paper also investigates the efficiency of both capital and labor elasticity of the two mentioned form of Cobb-Douglas production function. The estimated results shows that the estimates of both capital and labor elasticity of Cobb-Douglas production function with additive errors are more efficient than those estimates of Cobb-Douglas production function with multiplicative errors.
\end{abstract}

Keywords Cobb-Douglas Production Function, Efficiency, Bangladesh.

AMS 2010 subject classifications 62F07, 62G05, 62J02, 65D15

DOI: $10.19139 /$ soic.v3i1.120

\section{Introduction}

In the present times, production takes place by the combination forces of various factors of production such as land, labor, capital etc. In this connection, socialist countries are using different patterns of level of factors of production for their respective industrialization policy according to the taste, demand and nature of their country-wide population, its size, location and environment. Bangladesh is a developing country. It is essential for Bangladesh to go for mass industrialization to strengthen the economy of Bangladesh for this purpose; of course our policy for industrialization must be well planned, well defined and well thoughtful. It is obvious that the development of economy is solely dependent on the industrial polices of the country. By using production function we can get industrial policies especially indication about the nature of the production inputs used in the production function.

\footnotetext{
${ }^{*}$ Correspondence to: Md. Moyazzem Hossain (Email: mmhmm.justat@gmail.com). Department of Statistics, Jahangirnagar University, Savar, Dhaka, Bangladesh
}

ISSN 2310-5070 (online) ISSN 2311-004X (print)

Copyright (C) 2015 International Academic Press 
The growth of a country can be measured by Gross Domestic Product (GDP). GDP is substantially affected by the industrial output. Industrial gross output is a function of capital and labor input mainly. If the effect of labor and capital input to output is at a satisfactory level in an industry or in a group of industries, then industrial investment will increases. As a result, the number of industries will increase, which will directly affect GDP and also will decrease the unemployment rate. This is why, industrial input-output relationship is so important for any industry as well as for the overall industrial sector of a country. A firm's output decision depends critically on the quantities of inputs it uses to produce the desired level of output. The production function analysis helps a firm to select the optimal combination of inputs by which it can produce the desired level of output with minimum cost and maximum profitability (Singh et al. [46]). In the present study, to investigate the productivity behaviour of some selected manufacturing industries in Bangladesh, we use the concept of production function. Nowadays, businessmen as well as industrialists are very much concerned about the theory of firm in order to make correct decisions regarding what items, how much and how to produce them. These decisions are directly related with cost considerations, markets situations where the firm is to be operated and internal organization of the firm (Harbury [35]). Here, the factor "firm" is very important due to the fact that it is the basic unit of production in producing goods and services such as transporting, financing, wholesaling and retailing using the factors of production such as labor and capital (Intriligator [38]).

Hoque [36], Bhatti [26], Baltagi [2], Bhatti and Owen [28], Bhatti [27], Bhatti et al. [29], Ingene and Lusch [37], Mok [44], Hossain et al. [42], Hajkova and Hurnik [34], Prajneshu [45], Antony [1], and Hossain et al. [43], amongst others who have used linear regression models to measure the log-linear Cobb-Douglas (C-D) type production processes. Hoque [36] used the survey data for Bangladesh to examine the relationship between farm size and production efficiency. The author estimated two Cobb-Douglas-type production functions both by ordinary least squares with fixed and random coefficients. The stochastic term in Cobb-Douglas type models is either specified to be additive or multiplicative (Stephen M. Goldfeld and Richard E. Quandt [47]). They developed a model in which a Cobb-Douglas type function is coupled with simultaneous multiplicative and additive errors.

In this paper, this paper choose and estimate the parameters of Cobb-Douglas function with additive errors and multiplicative errors for some selected manufacturing industries of Bangladesh, which should be helpful in suggesting the most suitable Cobb-Douglas production function to forecast the production process for some selected manufacturing industries of developing countries like Bangladesh. This paper also investigates the efficiency of both capital and labor elasticity of the two mentioned form of Cobb-Douglas production function.

The annual industrial data have been employed to estimate the function. In recent publications of "Statistical Yearbook of Bangladesh" [3]-[14] published by Statistics division, Ministry of Planning, Dhaka, Bangladesh and "Report on Bangladesh Census of Manufacturing Industries (CMI)" [15]-[25] published by Planning division, Ministry of Planning, Dhaka, Bangladesh, we collected the published secondary data for the major manufacturing industries of Bangladesh over the period 1978-79 to 2011-2012. Moreover, we could not use the latest data of manufacturing industries simply because the relevant data are not up to date in the ministry. We have chosen the following manufacturing industries for the ongoing analysis:

(i) Beverage (ii) Industrial Chemical (iii) Drugs \& pharmaceutical (iv) Furniture \& fixtures (wooden) (v) Glass \& glass products (vi) Leather \& leather products (vii) Paper \& paper products (viii) Plastic products (ix) Printing $\&$ publication (x) Textile (xi) Transport equipment (xii) Wood \& cork products.

The rest of this paper is organized as follows. Section 2 briefly discusses the theoretical concepts of the CobbDouglas production function with additive errors and multiplicative errors. Estimation procedure of both model discuss in Section 3. Results and discussion have been presented in Section 4. Section 5 concludes the paper.

\section{Cobb-Douglas Production Function}

The Cobb-Douglas production function is the widely used function in Econometrics. A famous case is the wellknown Cobb-Douglas production function introduced by Charles W. Cobb and Paul H. Douglas [31], although anticipated by Knut Wicksell and, some have argued, J. H. Von Thüen. They have estimated it after studying different industries in the world, for this it is used as a fairly universal law of production. 
The Cobb-Douglas production function with multiplicative error term can be represented as,

$$
P_{t}=A K_{t}^{\alpha} L_{t}^{\beta} u_{t}
$$

where, $P_{t}$ is the output at time $t ; L_{t}$ is the Labor input; $K_{t}$ is the Capital input; $A$ is a constant; $u_{t}$ is the random error term. $\alpha$ and $\beta$ are positive parameters and $\alpha>0, \beta>0$.

The Cobb-Douglas production function with additive error term can be represented as,

$$
P_{t}=A K_{t}^{\alpha} L_{t}^{\beta}+u_{t}
$$

where, $P_{t}$ is the output at time $t ; L_{t}$ is the Labor input; $K_{t}$ is the Capital input; $A$ is a constant; $u_{t}$ is the random error term. $\alpha$ and $\beta$ are positive parameters and $\alpha>0, \beta>0$.

\section{Estimation Procedure}

Equation (1) is nearly always treated as a linear relationship by making a logarithmic transformation, which yields:

$$
\log P_{t}=\log A+\alpha \log K_{t}+\beta \log L_{t}+\log u_{t}
$$

where, $\log u$ is treated as an additive random error with a zero mean. In this form the function is a single equation which is linear in the unknown parameters: $\log A, \alpha$ and $\beta$.

In the case of equation (2), the minimization of, $\sum_{t=1}^{T} u_{t}^{2}$ is no longer a simple linear estimation problem. To estimate the production function we need to know different types of non-linear estimation. In non-linear model it is not possible to give a closed form expression for the estimates as a function of the sample values, i.e., the likelihood function or sum of squares cannot be transformed so that the normal equations are linear. The idea of using estimates that minimize the sum squared errors is a data-analytic idea, not a statistical idea; it does not depend on the statistical properties of the observations (see Christensen, [30]). In most situation non-linear estimation problem can be solved by minimizing the error sum square estimation method using any of the optimization method (see Goldfeld and Quandt [33]). Newton-Raphson method [39] is one of the methods which is used to estimate the parameters of model (2).

In order to estimate the parameters we minimize the following error sum squares

$$
\sum_{t=1}^{T} u_{t}^{2}=\sum_{t=1}^{T}\left(P_{t}-A K_{t}^{\alpha} L_{t}^{\beta}\right)^{2}
$$

To estimate the parameters of the proposed Cobb-Douglas production function by using Newton-Raphson method [39], we need the Score vector and Hessian matrix of $\sum_{t=1}^{T} u_{t}^{2}$. The elements of Score vector of the proposed Cobb-Douglas production function are as:

$$
\begin{aligned}
& \frac{\partial \sum_{t=1}^{T} u_{t}^{2}}{\partial A}=-2 * \sum_{t=1}^{T}\left[\left(P_{t}-A K_{t}^{\alpha} L_{t}^{\beta}\right) *\left(K_{t}^{\alpha} L_{t}^{\beta}\right)\right] . \\
& \frac{\partial \sum_{t=1}^{T} u_{t}^{2}}{\partial \alpha}=-2 * \sum_{t=1}^{T}\left[\left(P_{t}-A K_{t}^{\alpha} L_{t}^{\beta}\right) *\left(\ln \left(K_{t}\right)\right) *\left(A K_{t}^{\alpha} L_{t}^{\beta}\right)\right] . \\
& \frac{\partial \sum_{t=1}^{T} u_{t}^{2}}{\partial \beta}=-2 * \sum_{t=1}^{T}\left[\left(P_{t}-A K_{t}^{\alpha} L_{t}^{\beta}\right) *\left(\ln \left(L_{t}\right)\right) *\left(A K_{t}^{\alpha} L_{t}^{\beta}\right)\right] .
\end{aligned}
$$


Also the elements of Hessian matrix are given below:

$$
\begin{aligned}
& \frac{\partial^{2} \sum_{t=1}^{T} u_{t}^{2}}{\partial A^{2}}=2 \sum_{t=1}^{T}\left(K_{t}^{\alpha} L_{t}^{\beta}\right)^{2} \\
& \frac{\partial^{2} \sum_{t=1}^{T} u_{t}^{2}}{\partial A \partial \alpha}=2 \sum_{t=1}^{T}\left[\left(\left(\ln \left(K_{t}\right)\right) *\left(A K_{t}^{\alpha} L_{t}^{\beta}\right) *\left(K_{t}^{\alpha} L_{t}^{\beta}\right)\right)-\left(\left(P_{t}-A K_{t}^{\alpha} L_{t}^{\beta}\right) *\left(\ln \left(K_{t}\right)\right) *\left(K_{t}^{\alpha} L_{t}^{\beta}\right)\right)\right] \\
& \frac{\partial^{2} \sum_{t=1}^{T} u_{t}^{2}}{\partial A \partial \beta}=2 \sum_{t=1}^{T}\left[\left(\left(\ln \left(L_{t}\right)\right) *\left(A K_{t}^{\alpha} L_{t}^{\beta}\right) *\left(K_{t}^{\alpha} L_{t}^{\beta}\right)\right)-\left(\left(P_{t}-A K_{t}^{\alpha} L_{t}^{\beta}\right) *\left(\ln \left(L_{t}\right)\right) *\left(K_{t}^{\alpha} L_{t}^{\beta}\right)\right)\right] \\
& \frac{\partial^{2} \sum_{t=1}^{T} u_{t}^{2}}{\partial \alpha^{2}}=2 \sum_{t=1}^{T}\left[\left(\left(\ln \left(K_{t}\right)\right) *\left(A K_{t}^{\alpha} L_{t}^{\beta}\right)\right)^{2}-\left(\left(P_{t}-A K_{t}^{\alpha} L_{t}^{\beta}\right) *\left(\ln \left(K_{t}\right)\right)^{2} *\left(A K_{t}^{\alpha} L_{t}^{\beta}\right)\right)\right] \\
& \frac{\partial^{2} \sum_{t=1}^{T} u_{t}^{2}}{\partial \alpha \partial \beta}=2 \sum_{t=1}^{T}\left[\left(\left(\ln \left(L_{t}\right)\right)\left(A K_{t}^{\alpha} L_{t}^{\beta}\right)\left(\ln \left(K_{t}\right)\right)\left(A K_{t}^{\alpha} L_{t}^{\beta}\right)\right)-\left(\left(P_{t}-A K_{t}^{\alpha} L_{t}^{\beta}\right)\left(\ln \left(L_{t}\right)\right)^{2}\left(A K_{t}^{\alpha} L_{t}^{\beta}\right)\right)\right] \\
& \frac{\partial^{2} \sum_{t=1}^{T} u_{t}^{2}}{\partial \beta^{2}}=2 \sum_{t=1}^{T}\left[\left(\left(\ln \left(L_{t}\right)\right) *\left(A K_{t}^{\alpha} L_{t}^{\beta}\right)\right)^{2}-\left(\left(P_{t}-A K_{t}^{\alpha} L_{t}^{\beta}\right) *\left(\ln \left(L_{t}\right)\right)^{2} *\left(A K_{t}^{\alpha} L_{t}^{\beta}\right)\right)\right]
\end{aligned}
$$

Hence the Score vector is

and Hessian matrix is

$$
G(\theta)=\left[\frac{\partial \sum_{t=1}^{T} u_{t}^{2}}{\partial A}, \frac{\partial \sum_{t=1}^{T} u_{t}^{2}}{\partial \alpha}, \frac{\partial \sum_{t=1}^{T} u_{t}^{2}}{\partial \beta}\right]^{\prime}
$$

$$
H(\theta)=\left[\begin{array}{ccc}
\frac{\partial^{2} \sum_{t=1}^{T} u_{t}^{2}}{\partial A^{2}} & \frac{\partial^{2} \sum_{t=1}^{T} u_{t}^{2}}{\partial A \partial \alpha} & \frac{\partial^{2} \sum_{t=1}^{T} u_{t}^{2}}{\partial A \partial \beta} \\
\frac{\partial^{2} \sum_{t=1}^{T} u_{t}^{2}}{\partial A \partial \alpha} & \frac{\partial^{2} \sum_{t=1}^{T} u_{t}^{2}}{\partial \alpha^{2}} & \frac{\partial^{2} \sum_{t=1}^{T} u_{t}^{2}}{\partial \alpha \partial \beta} \\
\frac{\partial^{2} \sum_{t=1}^{T} u_{t}^{2}}{\partial A \partial \beta} & \frac{\partial^{2} \sum_{t=1}^{T} u_{t}^{2}}{\partial \alpha \partial \beta} & \frac{\partial^{2} \sum_{t=1}^{T} u_{t}^{2}}{\partial \beta^{2}}
\end{array}\right]
$$

where, $\theta=(A, \alpha, \beta)^{\prime}$ is a vector of parameters. Now to estimate the parameters of Cobb-Douglas production function with additive errors we compute $\theta^{t+1}$ by using the following formula:

$$
\theta^{t+1}=\theta^{t}-\left[H\left(\theta^{t}\right)\right]^{-1} G\left(\theta^{t}\right),
$$

where $G(\theta)$ and $H(\theta)$ of our proposed Cobb-Douglas production function are given in equation (5) and (6) respectively. This is an iterative procedure. The iteration procedures continue until convergence is achieved. Near the maximum the rate of convergence is quadratic as define by

$$
\left|\theta_{i}^{t+1}-\hat{\theta}_{i}\right| \leq c\left|\theta_{i}^{t}-\hat{\theta}_{i}\right|^{2}
$$

for some $c \geq 0$ when $\theta_{i}^{t}$ is near $\hat{\theta}_{i}$ for all $i$. Thus we get estimates $\hat{\theta}_{i}$ of the vector of parameters of proposed Cobb-Douglas proposed production function by Newton-Raphson methods. 


\section{Results and Discussion}

\subsection{Estimation of Cobb-Douglas Production Function}

We estimate the multiplicative type Cobb-Douglas production function for different manufacturing industries mentions in previous section. The results are summarized in the following table:

Table 4.1 The estimates of Cobb-Douglas production function with multiplicative errors for different industries under study

\begin{tabular}{|c|c|c|c|c|c|c|c|c|c|}
\hline $\begin{array}{l}\text { Industry } \\
\text { name }\end{array}$ & $\begin{array}{l}\text { Intercept } \\
(\hat{A})\end{array}$ & S.E. $(\hat{A})$ & $\begin{array}{l}\text { Capital elas- } \\
\text { ticity }(\hat{\alpha})\end{array}$ & S.E. $(\hat{\alpha})$ & $\begin{array}{l}\text { Labor elas- } \\
\text { ticity }(\hat{\beta})\end{array}$ & S.E. $(\hat{\beta})$ & $\begin{array}{l}\text { Return } \\
\text { to scale } \\
(\hat{\alpha}+\hat{\beta})\end{array}$ & $\hat{\gamma}=\frac{1}{\hat{\alpha}+\hat{\beta}}$ & $R^{2}$ \\
\hline Beverage & 1.273508 & 0.21579 & 0.21486 & 0.11324 & 0.72105 & 0.15724 & 0.93591 & 1.068479 & 0.9378 \\
\hline $\begin{array}{l}\text { Industrial } \\
\text { Chemical }\end{array}$ & 3.01226 & 0.16479 & 0.31257 & 0.194324 & 0.544715 & 0.211324 & 0.857285 & 1.166473 & 0.9802 \\
\hline $\begin{array}{l}\text { Drugs \& } \\
\text { pharmaceuti- } \\
\text { cal }\end{array}$ & 2.162101 & 0.17779 & 0.492587 & 0.29524 & 0.421712 & 0.33224 & 0.914299 & 1.093734 & 0.9838 \\
\hline $\begin{array}{l}\text { Furniture } \\
\& \text { fixtures } \\
\text { (wooden) }\end{array}$ & 1.109825 & 0.32279 & 0.411478 & 0.27824 & 1.0126 & 0.19824 & 1.424078 & 0.702209 & 0.9243 \\
\hline $\begin{array}{l}\text { Glass \& glass } \\
\text { products }\end{array}$ & 2.37134 & 0.22679 & 0.11883 & 0.13724 & 0.814392 & 0.23224 & 0.933222 & 1.071556 & 0.9411 \\
\hline $\begin{array}{l}\text { Leather } \\
\& \text { leather } \\
\text { products }\end{array}$ & 5.014694 & 0.20179 & 0.210465 & 0.16024 & 0.610401 & 0.473324 & 0.820866 & 1.218225 & 0.9755 \\
\hline $\begin{array}{l}\text { Paper } \\
\& \quad \text { paper } \\
\text { products }\end{array}$ & 2.581465 & 0.87779 & 0.11423 & 0.352324 & 0.810542 & 0.330324 & 0.924772 & 1.081348 & 0.902 \\
\hline $\begin{array}{l}\text { Plastic prod- } \\
\text { ucts }\end{array}$ & 2.016844 & 0.25379 & 0.151365 & 0.25024 & 1.101678 & 0.31324 & 1.253043 & 0.798057 & 0.9589 \\
\hline $\begin{array}{l}\text { Printing \& \& } \\
\text { publication }\end{array}$ & 1.023192 & 0.23679 & 0.713265 & 0.117324 & 0.510165 & 0.284132 & 1.223429 & 0.817375 & 0.9942 \\
\hline Textile & 2.015652 & 0.37779 & 0.401512 & 0.175324 & 0.54185 & 0.362324 & 0.943362 & 1.060038 & 0.9798 \\
\hline $\begin{array}{l}\text { Transport } \\
\text { equipment }\end{array}$ & 1.20705 & 0.61879 & 0.131101 & 0.405324 & 1.11018 & 0.968324 & 1.241281 & 0.805619 & 0.9379 \\
\hline $\begin{array}{l}\text { Wood \& cork } \\
\text { products }\end{array}$ & 1.201496 & 0.33679 & 0.52316 & 0.17224 & 0.514104 & 0.291324 & 1.037264 & 0.964075 & 0.9529 \\
\hline
\end{tabular}

From Table 4.1, we observe that, there are economies of scale in the manufacturing of Printing \& publication, Plastic products, Furniture \& fixtures (wooden), Transport equipment and Wood \& cork products since $\gamma<1$ for these industries and there are diseconomies of scale in the Beverage, Leather \& leather products, Paper \& paper products, Glass \& glass products, Industrial chemicals, Textile, and Drug \& pharmaceutical industries since $\gamma>1$ for these industries. The results in Table 4.1 are obtained by applying Ordinary Least Square (OLS) method.

Also, we estimate the additive type Cobb-Douglas production function for different manufacturing industries mentions in previous section. The results are summarized in the following table:

The results given in Table 4.2 are obtained by using Newton-Raphson optimization technique. There are economies of scale in the manufacturing of Drugs \& pharmaceuticals, Furniture \& fixtures (wooden), Plastic products, Printing \& publications since $\gamma<1$ for these industries and there are diseconomies of scale in the Beverage, Industrial Chemical, Glass \& glass products, Leather \& leather products, Paper \& paper products, Textile, Wood \& crock products industries, Transport equipment since $\gamma>1$ for these industries.

From Table 4.3, we observe that the estimate of capital elasticity of Cobb-Douglas production function with additive errors is more efficient than the estimate of capital elasticity of Cobb-Douglas production function with multiplicative errors.

The variance of the estimates of capital elasticity for all selected manufacturing industries is higher for CobbDouglas production function with multiplicative errors than multiplicative errors. There is slight difference between the variances of the estimates of capital elasticity for the manufacturing industries namely Drugs \& pharmaceutical, Leather \& leather products, Printing \& publication and Wood \& cork products and a big difference is observed for the manufacturing industries namely Furniture \& fixtures (wooden), paper \& paper products and Transport equipment (Figure 4.1). 


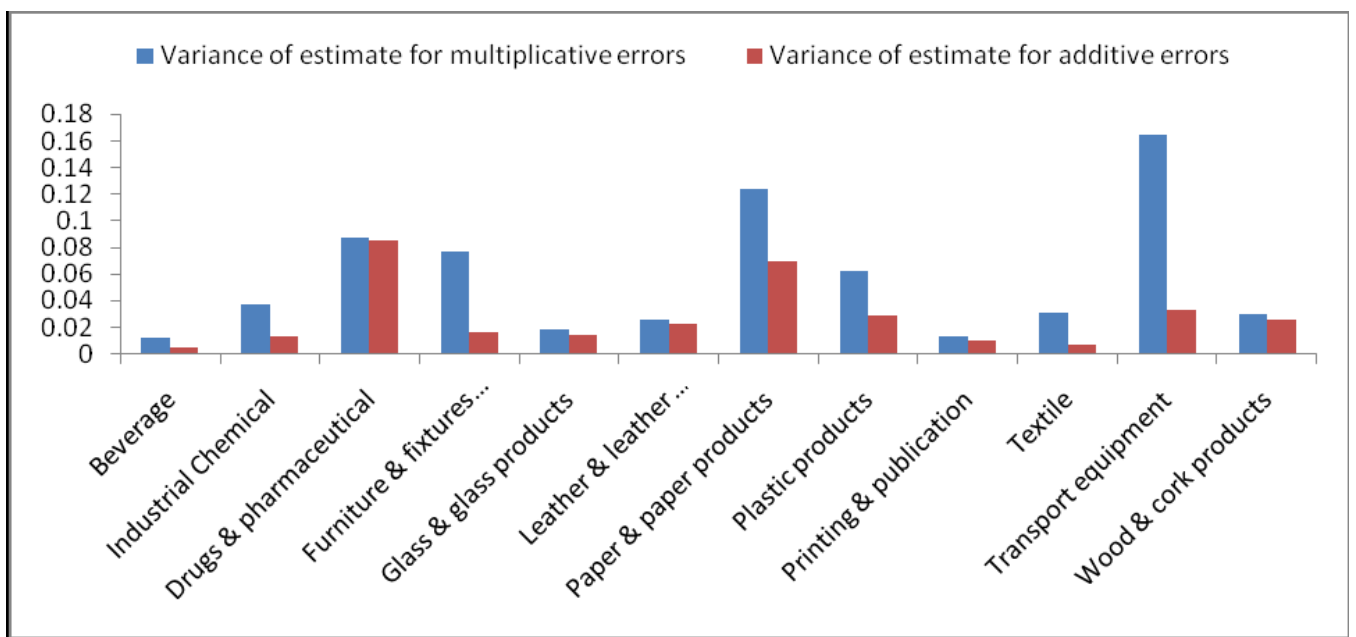

Figure 4.1: Efficiency of capital elasticity the estimate of Cobb-Douglas production function with additive errors and CobbDouglas production function with multiplicative errors.

Table 4.2 The estimates of Cobb-Douglas production function with additive errors for different industries under study.

\begin{tabular}{|c|c|c|c|c|c|c|c|c|c|}
\hline Industry name & $\begin{array}{l}\text { Intercept } \\
(\hat{A})\end{array}$ & S.E. $(\hat{A})$ & $\begin{array}{l}\text { Capital elas- } \\
\text { ticity }(\hat{\alpha})\end{array}$ & S.E. $(\hat{\alpha})$ & $\begin{array}{l}\text { Labor elastic- } \\
\text { ity }(\hat{\beta})\end{array}$ & S.E. $(\hat{\beta})$ & $\begin{array}{l}\text { Return } \\
\text { to } \text { scale } \\
(\hat{\alpha}+\hat{\beta})\end{array}$ & $\hat{\gamma}=\frac{1}{\hat{\alpha}+\hat{\beta}}$ & $R^{2}$ \\
\hline Beverage & 6.00151 & 2.98679 & 0.710336 & 0.07534 & 0.23021 & 0.129342 & 0.940546 & 1.063212 & 0.9709 \\
\hline $\begin{array}{l}\text { Industrial Chemi- } \\
\text { cal }\end{array}$ & 6.553109 & 3.44179 & 0.610725 & 0.11521 & 0.241343 & 0.12021 & 0.852068 & 1.173615 & 0.9733 \\
\hline $\begin{array}{l}\text { Drugs \& pharma- } \\
\text { ceutical }\end{array}$ & 1.50116 & 0.48879 & 0.68104 & 0.29121 & 0.49783 & 0.28821 & 1.17887 & 0.84827 & 0.9956 \\
\hline $\begin{array}{l}\text { Furniture \& fix- } \\
\text { tures (wooden) }\end{array}$ & 1.136145 & 0.13279 & 1.153312 & 0.12914 & 0.32416 & 0.129135 & 1.477472 & 0.676832 & 0.9813 \\
\hline $\begin{array}{l}\text { Glass \& glass } \\
\text { products }\end{array}$ & 11.13615 & 3.42979 & 0.546121 & 0.12121 & 0.301205 & 0.17921 & 0.847326 & 1.180183 & 0.9545 \\
\hline $\begin{array}{l}\text { Leather \& leather } \\
\text { products }\end{array}$ & 150.0012 & 38.3548 & 0.31352 & 0.1514 & 0.400121 & 0.25844 & 0.713641 & 1.401265 & 0.9642 \\
\hline $\begin{array}{l}\text { Paper \& paper } \\
\text { products }\end{array}$ & 37.1003 & 49.6938 & 0.16444 & 0.26456 & 0.610326 & 0.16656 & 0.774766 & 1.290713 & 0.7956 \\
\hline Plastic products & 10.10537 & 0.76291 & 0.08215 & 0.17087 & 0.957626 & 0.22187 & 1.039776 & 0.961746 & 0.9155 \\
\hline $\begin{array}{l}\text { Printing \& publi- } \\
\text { cation }\end{array}$ & 1.01334 & 0.24679 & 1.059818 & 0.10429 & 0.220124 & 0.177034 & 1.279942 & 0.781285 & 0.9910 \\
\hline Textile & 33.43128 & 31.3147 & 0.60034 & 0.08654 & 0.233019 & 0.16654 & 0.833359 & 1.199963 & 0.9580 \\
\hline $\begin{array}{l}\text { Transport equip- } \\
\text { ment }\end{array}$ & 35.2223 & 46.8248 & 0.04527 & 0.18161 & 0.813132 & 0.35361 & 0.858402 & 1.164955 & 0.7434 \\
\hline $\begin{array}{l}\text { Wood \& cork } \\
\text { products }\end{array}$ & 46.01417 & 24.7437 & 0.061234 & 0.16269 & 0.467334 & 0.187569 & 0.528568 & 1.891904 & 0.9310 \\
\hline
\end{tabular}

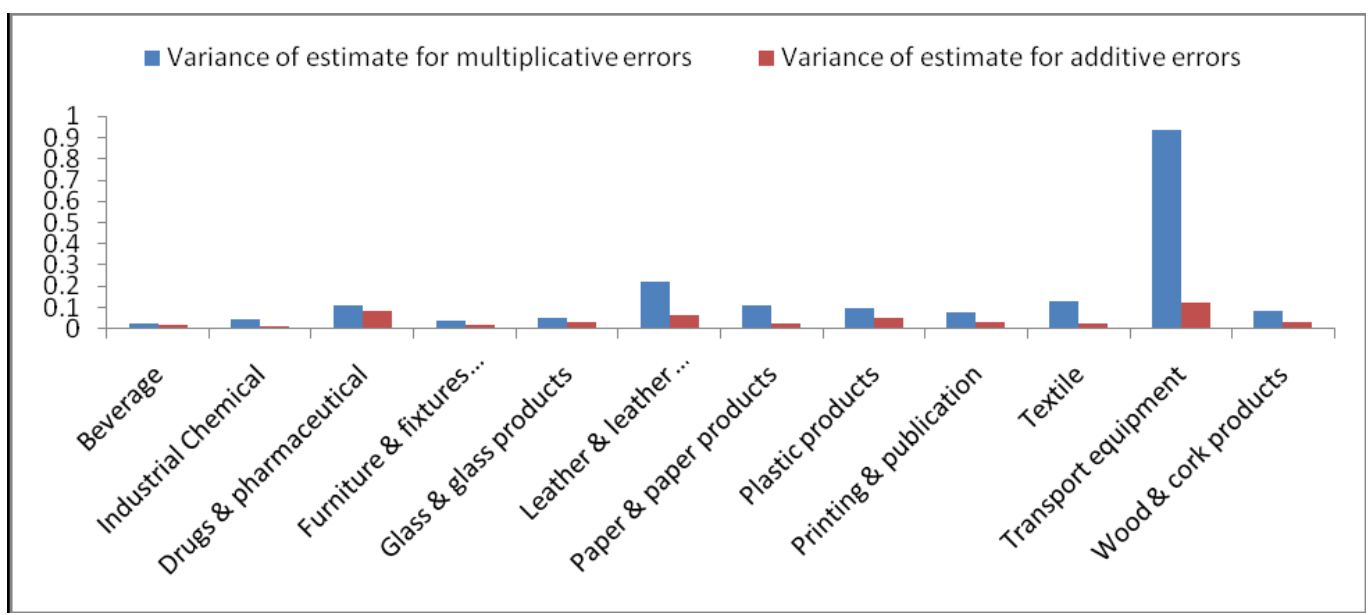

Figure 4.2: Efficiency of labor elasticity the estimate of Cobb-Douglas production function with additive errors and CobbDouglas production function with multiplicative errors. 
Table 4.3 Efficiency of capital elasticity the estimate of Cobb-Douglas production function with additive errors with respect to Cobb-Douglas production function with multiplicative errors.

\begin{tabular}{|l|l|l|l|}
\hline Name of industry & $\begin{array}{l}\text { Variance of estimate for } \\
\text { multiplicative errors }\end{array}$ & $\begin{array}{l}\text { Variance of estimate } \\
\text { for additive errors }\end{array}$ & $\begin{array}{l}\text { Efficiency of estimate for additive } \\
\text { errors with respect to the estimate } \\
\text { for multiplicative errors }\end{array}$ \\
\hline Beverage & 0.012823 & 0.005676 & 2.259042 \\
\hline $\begin{array}{l}\text { Industrial Chemi- } \\
\text { cal }\end{array}$ & 0.037762 & 0.013273 & 2.844936 \\
\hline $\begin{array}{l}\text { Drugs \& pharma- } \\
\text { ceutical }\end{array}$ & 0.087167 & 0.084803 & 1.027869 \\
\hline $\begin{array}{l}\text { Furniture \& fix- } \\
\text { tures (wooden) }\end{array}$ & 0.077417 & 0.016676 & 4.642492 \\
\hline $\begin{array}{l}\text { Glass \& glass } \\
\text { products }\end{array}$ & 0.018835 & 0.014692 & 1.28199 \\
\hline $\begin{array}{l}\text { Leather \& leather } \\
\text { products \& paper }\end{array}$ & 0.025677 & 0.022922 & 1.120186 \\
\hline $\begin{array}{l}\text { Paper \& } \\
\text { products }\end{array}$ & 0.124132 & 0.069992 & 1.77352 \\
\hline Plastic products & 0.06262 & 0.029197 & 1.265576 \\
\hline $\begin{array}{l}\text { Printing \& publi- } \\
\text { cation }\end{array}$ & 0.013765 & 0.010876 & 4.104393 \\
\hline Textile & 0.030739 & 0.032982 & 4.981098 \\
\hline $\begin{array}{l}\text { Transport } \\
\text { equipment }\end{array}$ & 0.164288 & 0.026468 & \\
\hline $\begin{array}{l}\text { Wood \& cork } \\
\text { products }\end{array}$ & 0.029667 & & \\
\hline
\end{tabular}

Table 4.4 Efficiency of labor elasticity the estimate of Cobb-Douglas production function with additive errors with respect to Cobb-Douglas production function with multiplicative errors.

\begin{tabular}{|c|c|c|c|}
\hline Name of industry & $\begin{array}{lr}\text { Variance } & \text { of } \\
\text { estimate } & \text { for } \\
\text { multiplicative } & \\
\text { errors } & \end{array}$ & $\begin{array}{l}\text { Variance of esti- } \\
\text { mate for additive } \\
\text { errors }\end{array}$ & $\begin{array}{l}\text { Efficiency of estimate for additive } \\
\text { errors with respect to the estimate for } \\
\text { multiplicative errors }\end{array}$ \\
\hline Beverage & 0.024724 & 0.016729 & 1.477904 \\
\hline Industrial Chemical & 0.044658 & 0.01445 & 3.090412 \\
\hline Drugs \& pharmaceutical & 0.110383 & 0.083065 & 1.32888 \\
\hline $\begin{array}{l}\text { Furniture } \\
\text { (wooden) }\end{array} \quad \& \quad$ fixtures & 0.039299 & 0.016676 & 2.356648 \\
\hline Glass \& glass products & 0.053935 & 0.032116 & 1.679382 \\
\hline Leather \& leather products & 0.224036 & 0.066791 & 3.354267 \\
\hline Paper \& paper products & 0.109114 & 0.027742 & 3.933135 \\
\hline Plastic products & 0.098119 & 0.049226 & 1.993229 \\
\hline Printing \& publication & 0.080731 & 0.031341 & 2.575887 \\
\hline Textile & 0.131279 & 0.027736 & 4.733224 \\
\hline Transport equipment & 0.937651 & 0.12504 & 7.498809 \\
\hline Wood \& cork products & 0.08487 & 0.035182 & 2.412295 \\
\hline
\end{tabular}

From Table 4.4, we observe that the estimate of capital elasticity of Cobb-Douglas production function with additive errors is more efficient than the estimate of capital elasticity of Cobb-Douglas production function with multiplicative errors.

The variance of the estimates of labor elasticity for all selected manufacturing industries is higher for CobbDouglas production function with multiplicative errors than multiplicative errors. It is observed that there is a big difference between the variances of the estimates of labor elasticity for the manufacturing industries namely Leather \& leather products and Transport equipment (Figure 4.2). 


\section{Conclusions}

We estimate the parameters of Cobb-Douglas production function with multiplicative errors (intrinsically linear model) and Cobb-Douglas production function with additive errors (intrinsically nonlinear model). Cobb-Douglas production function with multiplicative errors and Cobb-Douglas production function with additive errors give different estimates. So that, in order to forecast about the production of a manufacturing industry in Bangladesh, to identify the appropriate Cobb-Douglas production function as well as efficient estimators. For this purpose, we compute the efficiency of both capital and labor elasticity of Cobb-Douglas production function with additive errors and multiplicative errors. We observed that Cobb-Douglas production function with additive errors is more efficient than those estimates of Cobb-Douglas production function with multiplicative errors.

\section{REFERENCES}

1. Antony, J. (2009). A dual elasticity of substitution production function with an application to cross-country inequality. Economics Letters, 102, 10-12.

2. Baltagi, B. H. (1996). Econometrics Analysis of Panel Data, John Wiley, New York, NY.

3. Bangladesh Bureau of Statistics (1981). Statistical Yearbook of Bangladesh, Ministry of Planning, Government of Bangladesh, Dhaka.

4. Bangladesh Bureau of Statistics (1984). Statistical Yearbook of Bangladesh, Ministry of Planning, Government of Bangladesh, Dhaka

5. Bangladesh Bureau of Statistics (1986). Statistical Yearbook of Bangladesh, Ministry of Planning, Government of Bangladesh, Dhaka.

6. Bangladesh Bureau of Statistics (1995). Statistical Yearbook of Bangladesh, Ministry of Planning, Government of Bangladesh, Dhaka.

7. Bangladesh Bureau of Statistics (1997). Statistical Yearbook of Bangladesh, Ministry of Planning, Government of Bangladesh, Dhaka.

8. Bangladesh Bureau of Statistics (2000). Statistical Yearbook of Bangladesh, Ministry of Planning, Government of Bangladesh, Dhaka.

9. Bangladesh Bureau of Statistics (2001). Statistical Yearbook of Bangladesh, Ministry of Planning, Government of Bangladesh, Dhaka.

10. Bangladesh Bureau of Statistics (2003). Statistical Yearbook of Bangladesh, Ministry of Planning, Government of Bangladesh, Dhaka.

11. Bangladesh Bureau of Statistics (2005). Statistical Yearbook of Bangladesh, Ministry of Planning, Government of Bangladesh, Dhaka

12. Bangladesh Bureau of Statistics (2008). Statistical Yearbook of Bangladesh, Ministry of Planning, Government of Bangladesh, Dhaka

13. Bangladesh Bureau of Statistics (2010). Statistical Yearbook of Bangladesh, Ministry of Planning, Government of Bangladesh, Dhaka.

14. Bangladesh Bureau of Statistics (2012). Statistical Yearbook of Bangladesh, Ministry of Planning, Government of Bangladesh, Dhaka

15. Bangladesh Bureau of Statistics (1984). Reports on Bangladesh Census of Manufacturing Industries, Planning division, Ministry of Planning, Dhaka, Bangladesh.

16. Bangladesh Bureau of Statistics (1987). Reports on Bangladesh Census of Manufacturing Industries, Planning division, Ministry of Planning, Dhaka, Bangladesh.

17. Bangladesh Bureau of Statistics (1992). Reports on Bangladesh Census of Manufacturing Industries, Planning division, Ministry of Planning, Dhaka, Bangladesh.

18. Bangladesh Bureau of Statistics (1997). Reports on Bangladesh Census of Manufacturing Industries, Planning division, Ministry of Planning, Dhaka, Bangladesh.

19. Bangladesh Bureau of Statistics (2000). Reports on Bangladesh Census of Manufacturing Industries, Planning division, Ministry of Planning, Dhaka, Bangladesh.

20. Bangladesh Bureau of Statistics (2002). Reports on Bangladesh Census of Manufacturing Industries, Planning division, Ministry of Planning, Dhaka, Bangladesh.

21. Bangladesh Bureau of Statistics (2004). Reports on Bangladesh Census of Manufacturing Industries, Planning division, Ministry of Planning, Dhaka, Bangladesh.

22. Bangladesh Bureau of Statistics (2007). Reports on Bangladesh Census of Manufacturing Industries, Planning division, Ministry of Planning, Dhaka, Bangladesh.

23. Bangladesh Bureau of Statistics (2009). Reports on Bangladesh Census of Manufacturing Industries, Planning division, Ministry of Planning, Dhaka, Bangladesh.

24. Bangladesh Bureau of Statistics (2011). Reports on Bangladesh Census of Manufacturing Industries, Planning division, Ministry of Planning, Dhaka, Bangladesh.

25. Bangladesh Bureau of Statistics (2012). Reports on Bangladesh Census of Manufacturing Industries, Planning division, Ministry of Planning, Dhaka, Bangladesh.

26. Bhatti, M. I. (1993). Efficient estimation of random coefficient models based on survey data. Journal of Quantitative Economics, 9(1), 99-110.

27. Bhatti, M. I. (1997). A UMP invariant test for testing block effects: an example. Far East Journal of Theoretical Statistics, 1(1), 39-50.

28. Bhatti, M. I. and Owen, D. (1996). An econometrics analysis of agricultural performance in Sichuan, China. Asian Profile, 26(6), 443-57.

29. Bhatti, M.I., Khan, I.H. and Czerkawski, C. (1998). Agricultural productivity in Shanghai region of China: an econometric analysis. Journal of Economic Sciences, 1(2), 1-12.

30. Christensen R. (2001). Advance Linear Modelling, $2^{\text {nd }}$ ed., Springer, New York.

31. Cobb, C. W., and Douglas, P. H. (1928). A Theory of Production. American Economic Review, 8(1), 139-165.

32. Craven, P., Wahba, G. (1978). Smoothing noisy data with spline functions. Numer. Math., 31(4), 377-390.

33. Goldfield S. M. and Quandt R. E. (1973). Nonlinear Methods of Econometrics, North-Holland publication Company, Amsterdam, New York. 
34. Hajkova,A. D. and Hurnik, J. (2007). Cobb-Douglas production function: the case of a converging economy. Czech Journal of Economics and Finance, 57, 9-10.

35. Harbury, C. (1968). Workbook in Introductory Economics, Pergamon Press, New York, NY.

36. Hoque, I. (1991). An application and test of random coefficient model in Bangladesh agriculture. Journal of Applied Econometrics, 6, 77-90.

37. Ingene, C. A. and Lusch, R. F. (1999). Estimation of a department store production function. International Journal of Physical, Distribution \& Logistics Management, 29, 453-64.

38. Intriligator, M. D. (1980). Econometric Models, Techniques and Applications, Prentice-Hall, New York, NY.

39. Judge, G. G., Griffiths, W. E., Hill, R, C., Lutkephol, H., and Lee, T. C. (1985). The Theory and Practice of Econometrics, $2^{\text {nd }}$ ed., John Wiley and Sons, New York.

40. Kelejian, H. H. (1972). The Estimation of Cobb-Douglas Type Functions with Multiplicative and Additive Errors: A Further Analysis International Economic Review, 13, 179-182.

41. Khan, I.H., Bhatti, M.I. and Czerkawski, C. (1998). Indicator analysis approach to medium-term employment: Australian case study. Journal of Economic Studies, 2(9), 9-32.

42. Md. Zakir Hossain, M. Ishaq Bhatti, Md Zulficar Ali, (2004). An econometric analysis of some major manufacturing industries: A case study. Managerial Auditing Journal, 19(6), 790 - 795. doi: $10.1108 / 02686900410543895$

43. Md. Zakir Hossain, Khalid Said Al-Amri (2010). Use of Cobb-Douglas production model on some selected manufacturing industries in Oman. Education, Business and Society: Contemporary Middle Eastern Issues, 3(2), 78-85. doi:10.1108/17537981011047925

44. Mok, V. W. K. (2002). Industrial productivity in China: the case of the food industry in Guangdong province. Journal of Economic Studies, 29, 423-31.

45. Prajneshu (2008). Fitting of Cobb-Douglas production functions: revisited. Agricultural Economics Research Review, 21, $289-92$.

46. Singh, S. P., Parashar, A. K. and Singh, H. P. (1999). Econometrics and Mathematical Economics, S. Chand \& Company, New Delhi

47. Stephen M. Goldfeld and Richard E. Quandt (1970). The Estimation of Cobb-Douglas Type Functions with Multiplicative and Additive. International Economic Review, 11(2), 251-257. 